O.M. Grytsenko ${ }^{a}$, O.P. Naumenko ${ }^{b}$, O.V. Suberlyak ${ }^{a}$, L. Dulebova ${ }^{c}$, B.V. Berezhnyy ${ }^{a}$

\title{
OPTIMIZATION OF THE TECHNOLOGICAL PARAMETERS OF THE GRAFT COPOLYMERIZATION OF 2-HYDROXYETHYL METHACRYLATE WITH POLYVINYLPYRROLIDONE FOR NICKEL DEPOSITION FROM SALTS
}

\author{
${ }^{a}$ Lviv Polytechnic National University, Lviv, Ukraine \\ ${ }^{b}$ Ukrainian State University of Chemical Technology, Dnipro, Ukraine \\ c Technical University of Košice, Košice, Slovakia
}

\begin{abstract}
The basic technological parameters of the preparation of nickel-filled hydrogel materials based on copolymers of polyvinylpyrrolidone with 2-hydroxyethyl methacrylate by the method of polymerization with simultaneous recovery of metal ions were considered. It was established by volumetric method that the process of chemical reduction of nickel ions at $\mathrm{pH} 7.5-8$ is characterized by a high rate and a small induction period at a temperature of $60-70^{\circ} \mathrm{C}$. The presence of polyvinylpyrrolidone was found to reduce the duration of the induction period and increase the rate of the reduction reaction. The duration of the induction period is 14 minutes when the content of polyvinylpyrrolidone in solution is $200 \mathrm{~g} / \mathrm{L}$. The kinetics of heat release during copolymerization of 2-hydroxyethyl methacrylate with polyvinylpyrrolidone initiated by benzoyl peroxide was investigated by a thermometric method. It was established that the exothermic effect of the polymerization can be used to ensure the required temperature conditions for $\mathrm{Ni}^{2+}$ reduction. The versatile effect of the composition of the original polymer-monomer composition on the basic parameters of the exothermic process of copolymerization has been experimentally shown. The diversified effect of the composition of the initial polymer-monomer composition on the parameters of the exothermicity of the copolymerization was experimentally determined. The simplexlattice planning method was used to optimize the formula of polymer-monomer composition. The obtained regression equations allow establishing analytical dependences of the parameters of exothermic processes on the technological conditions of the reduction of $\mathrm{Ni}^{2+}$ ions and the formula of the polymer-monomer composition.
\end{abstract}

Keywords: polyvinylpyrrolidone, 2-hydroxyethylmethacrylate, metal-filled hydrogels, exothermic polymerization, chemical reduction, optimization, simplex-lattice planning.

DOI: $10.32434 / 0321-4095-2020-128-1-25-32$

\section{Introduction}

Nowadays, much attention is being paid to the polymeric composites filled with particles of metal nature $[1,2]$. Particular attention deserves composite metal-filled hydrogel materials $[3,4]$. The first type of hydrogels are formed on the basis of lightly crosslinked hydrophilic matrices, which swell due to the sorption of a limited volume of water and, as a rule, undergo a physical transition from vitreous to a highelastic state. Because of these processes, they become similar to biological tissues. This similarity determines the use of such materials mainly in biomedical practice $[5,6]$. Great interest to metal-filled hydrogels is due to their specific properties, in particular, controlled electrical conductivity, magnetic susceptibility, antibacterial action, antithrombogenicity, etc. These properties are achieved via the filling hydrogels with dispersed metals of a different nature [7,8]. The choice of the method to obtain metal-filled hydrogels affects the formation of their properties. The easiest way to prepare metalfilled hydrogels is to mix the initial reaction composition with a fine-dispersed powder of metal before polymerizing [9].

The reactive polymer-monomeric compositions (PMC) based on polyvinylpyrrolidone (PVP) with 2-hydroxyethylmethacrylate (HEMA/PVP) can be used for the fabrication of a sorption-capable matrix 
[10]. They are interesting both in their multifunctionality and in increased reactive ability due to the physical interaction of PVP with the metal surface. It should be noted that the preparation of a metal-hydrogel with the use of metallic powders is distinguished not only by the simplicity of the method and a positive effect of providing specific properties, but also by a number of disadvantages: the growth of heterogeneity of filling, the anisotropy of properties, the mass of the composite and the deterioration of its strength and homogeneity.

The method of $\mathrm{Ni}^{2+}$ reduction in a polymer matrix can be used to obtain nanocomposites through the pre-sorption of recovery precursors from their aqueous solutions [11]. However, this method is at least two-stage and accompanied by considerable consumption of oxidant and reducing agent solutions. In view of this, the urgent problem in the production of polymeric and composite materials is the development of new uncomplicated, highly effective techniques to synthesize metal-filled copolymers PVP and hydrogel materials on their basis.

We were the first who proposed a new method for the preparation of the metal-hydrogels based on copolymers HEMA with PVP (pHEMA-gr-PVP), which consists in the implementation of polymerization with simultaneous reduction of metal ions $[7,8]$. The choice of nickel as a filler is due to the special interest of the researchers [12]. The obtained nickel-hydrogel composites are promising as new materials which are characterized by enhanced magnetic, electrical conductive and catalytic properties and can be used as implantable electrochemical biosensors, electro-stimulated drug release, in chemical catalysis (for example, in reduction reaction of nitrophenols and in hydrogen production reactions), etc.

The combination of two different in nature chemical processes evidently makes difficulties in preparing materials with predictable properties. The structure and properties of any polymer are determined by the technology of its fabrication. The properties of metal-filled hydrogels will be determined by the nature of the distribution of the metal-filler particles in a polymer matrix and their characteristics. At the same time, the technological conditions of the reduction reaction, which, in this case, depend on the parameters of the exothermic polymerization reaction, affect the structure and the dispersity of the metals particles. In view of this, the purpose of this work was to investigate and substantiate the basic technological parameters of the preparation of the nickel-filled composites based on copolymers HEMA with PVP (Ni/pHEMA-gr-PVP), which were obtained by polymerization with simultaneous $\mathrm{Ni}^{2+}$ reduction.

\section{Materials and methods}

Lightly cross-linked polymers obtained by radical polymerization of HEMA at the presence of PVP were selected as a matrix for filling. The compositions with the ratio HEMA:PVP $=(90-60):(10-40)$ (in mass parts, m.p.) with $10-50$ m.p. of solvent $\left(\mathrm{H}_{2} \mathrm{O}\right)$ were studied.

The reduction of nickel ions was carried out using nickel sulfate $\left(\mathrm{NiSO}_{4} \cdot 7 \mathrm{H}_{2} \mathrm{O}\right)$ by sodium hypophosphite $\left(\mathrm{NaH}_{2} \mathrm{PO}_{2} \cdot \mathrm{H}_{2} \mathrm{O}\right)$. The oxidationreduction system was obtained by the addition of certain amounts of $\mathrm{NiSO}_{4}(0.011-1.1 \mathrm{~mol} / \mathrm{L})$, sodium acetate $(20 \mathrm{~g} / \mathrm{L})$ and $\mathrm{NaH}_{2} \mathrm{PO}_{2}(0.024-2.4$ $\mathrm{mol} / \mathrm{L}$ ) to water. The $\mathrm{pH}$ of the solution was adjusted by concentrated acetic acid and $25 \%$ solution of ammonia. A reduction activator, in particular $2 \%$ solution of $\mathrm{AgNO}_{3}$, was introduced into the oxidation-reduction system in order to increase the activity of the reducing agent.

Polymerization was carried out with the initiator of a radical type of benzoyl peroxide (BP). 2-hydroxyethylmethacrylate (Sigma Chemical Co) and polyvinylpyrrolidone (AppliChem $\mathrm{GmbH}$ ) of high purity with $M M=12000$ were used for copolymerization. HEMA was distilled off in vacuum (with a residual pressure of $130 \mathrm{~N} / \mathrm{m}^{2}, \mathrm{~T}_{\mathrm{b}}=351 \mathrm{~K}$ ); PVP was dried at $338 \mathrm{~K}$ in vacuum for $2-3 \mathrm{~h}$; BP was recrystallized from ethanol. Inorganic salts (nickel sulfate, sodium hypophosphite, iron (II) sulfate and silver nitrate) were reagent grade.

Preparation of the Ni/pHEMA-gr-PVP composites was performed according to the method described elsewhere [8]. The kinetics of the chemical reduction of nickel ions was evaluated by volumetric method (the measurement of the volume of hydrogen evolved) [13]. The temperature changes of the reaction medium during the polymerization reaction were investigated by a thermometric method [8].

\section{Results and discussion}

The high reactivity of HEMA/PVP compositions is a prerequisite for implementation of the developed method for the preparation of metalfilled pHEMA-gr-PVP copolymers, as well as the possibility of the polymerization implementation in the presence of a solvent $\left(\mathrm{H}_{2} \mathrm{O}\right)$ to achieve high porosity of the polymer matrix and, consequently, ensure the removal of the reduction reaction products from the composites volume. In addition, polymerization is accompanied by an exothermic effect; hence, the heat of the reaction can be used to provide the required temperature conditions for the reduction of nickel ions. 
The polymerization method to form metal-filled hydrogels with simultaneous chemical reduction of metal ions involves substantiating and establishing the optimal technological parameters for its implementation. One of the important process stages is the deposition of metal-filler particles. We choose the method of nickel ions chemical reduction by hypophosphite according to the following reaction:

$$
\begin{aligned}
& \mathrm{NiSO}_{4}+2 \mathrm{NaH}_{2} \mathrm{PO}_{2}+2 \mathrm{H}_{2} \mathrm{O} \rightarrow \\
& \rightarrow \mathrm{Ni} \downarrow+2 \mathrm{NaH}_{2} \mathrm{PO}_{3}+\mathrm{H}_{2} \mathrm{SO}_{4}+\mathrm{H}_{2} \uparrow .
\end{aligned}
$$

This method is characterized by high productivity, technological availability, and wide range of possibilities to regulate the rate of the process, compositions and properties of metallic powders. In addition, it does not require complicated equipment. Besides, the use of nickel-hypophosphite solutions with organic ligands allows preparing a metal with a high corrosion resistance [12].

The kinetic parameters, induction period duration of the reduction reaction $\left(\tau_{\mathrm{i}}\right)$, reduction time $\left(\tau_{\mathrm{r}}\right)$, and the maximum reduction rate $\left(\mathrm{V}_{\mathrm{r}}{ }^{\max }\right)$, were determined for $\mathrm{Ni}^{2+}$ reduction processes by using the volumetric method. The induction period of the reduction reaction is the initial stage, which is characterized by kinetic inhibition. During this reaction period, the stable particles of solid phase are formed in the solution, which will show autocatalytic effect in the future. Both the duration of the formation of solid phase particles and the induction period depends on various factors.

At the same time, the copolymerization of HEMA with PVP and formation of a graft copolymer pHEMA-gr-PVP occur through the stage that involves the polymerization induction period. This is characterized by a start time of gel formation $\left(\tau_{\text {s.f. }}\right)$ and the stage of the gel effect, as a results of which

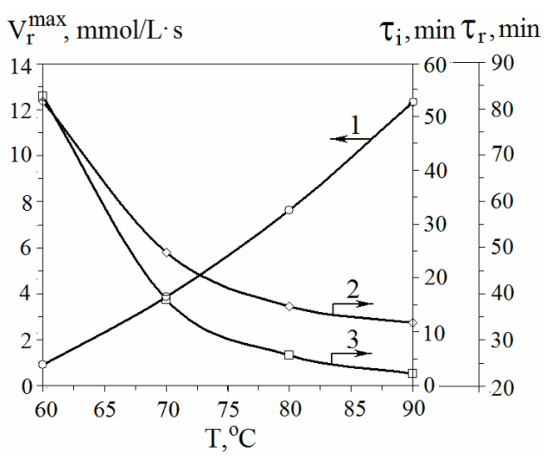

a the system being heated to the maximum exothermic temperature $\left(T_{\max }\right)$ in the reaction $[7,8]$. The stage of the gel effect was characterized by the duration of gel effect area $\left(\tau_{\text {d.e. }}\right)$. In our case, it is important that the duration of the $\mathrm{Ni}^{2+}$ reduction process approaches the duration of gel effect area of the polymerization reaction with a minimum start time of gel formation and a maximum $\mathrm{T}_{\max }$. For compositions containing more than 10 m.p. $\mathrm{H}_{2} \mathrm{O}$, the $\mathrm{T}_{\max }$ limit is $102-105^{\circ} \mathrm{C}$, since at higher temperatures they boil.

The rate and the degree of conversion in the $\mathrm{Ni}^{2+}$ reduction reaction depend on various factors: $\mathrm{pH}$, temperature and the presence of the activator [12]. It is known that the reduction by hypophosphite intensively proceeds at the temperature of $90-95^{\circ} \mathrm{C}$ in acidic or alkaline medium [12]. However, at these temperatures, the polymerization of HEMA/PVP compositions occurs with a high rate. In addition, this is an exothermic process. Therefore, it is necessary to ensure favorable conditions to provide the passage of the polymerization and reduction reactions at significantly lower temperatures.

The introduction of activators into a system is one of the conditions for the reaction of $\mathrm{Ni}^{2+}$ reduction with a high rate. A solution of $\mathrm{AgNO}_{3}$ (2\%) was used as a reduction activator in this work. In the absence of an activator, the reaction does not practically occur or occurs at a very low rate [12]. It was established that the use of the activator in the amount of $0.25 \mathrm{~g} / \mathrm{L}$ in an alkaline medium $(\mathrm{pH} 8)$ allows performing the reduction of $\mathrm{Ni}^{2+}$ ions at $60^{\circ} \mathrm{C}$ with high rate and minimal values of $\tau_{\mathrm{i}}$ and $\tau_{\mathrm{r}}$. If the temperature rises, the reduction rate increases (Fig. 1,a).

Water-soluble polymers, including PVP, are preferably used during the deposition of metals in small quantities as a stabilizer of metals particles [14]. In our case, PVP enters into the composition of the reaction mixture and participates in the

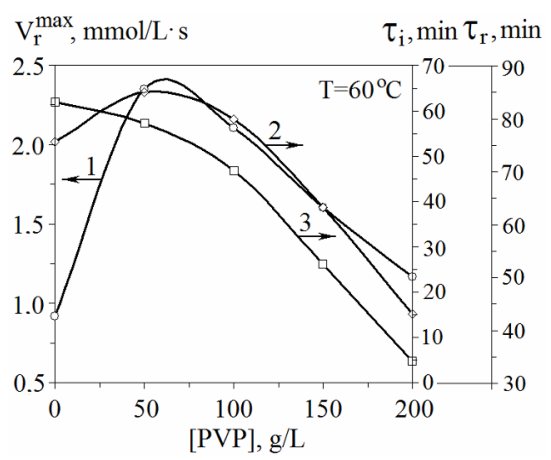

b

Fig. 1. Effects of temperature (a) and PVP content (b) on the kinetic parameters of nickel reduction $\left(\left[\mathrm{NiSO}_{4}\right]=0.55 \mathrm{~mol} / \mathrm{L}\right.$; $\left.\left[\mathrm{NaH}_{2} \mathrm{PO}_{2}\right]=1.2 \mathrm{~mol} / \mathrm{L} ;\left[\mathrm{AgNO}_{3}\right]=0.25 \mathrm{~g} / \mathrm{L}, \mathrm{pH} 8\right): 1-$ the maximum reduction rate $\left(\mathrm{V}_{\mathrm{r}}{ }^{\text {max }}\right) ; 2-$ the induction period duration of the reduction reaction $\left(\tau_{\mathrm{i}}\right)$; and $3-$ the reduction time $\left(\tau_{\mathrm{r}}\right)$

Optimization of the technological parameters of the graft copolymerization of 2-hydroxyethyl methacrylate with polyvinylpyrrolidone for nickel deposition from salts 
copolymerization reaction. PVP is used for copolymers synthesis in the amount of $150-200 \mathrm{~g} / \mathrm{L}$. As can be seen (Fig. 1,b), the addition of PVP allows accelerating significantly the reduction reaction at low temperatures. In addition, the presence of PVP affects the dispersion of metallic particles and their distribution in the polymer matrix $[7,8]$. Due to the complex formation, the attraction and concentration of metal ions on the PVP chain occurs (Fig. 2), which contributes to the formation of a greater number of active centers and prevents their integration.

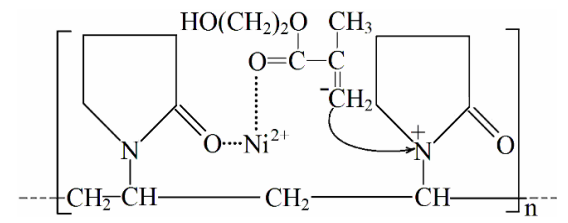

Fig. 2. Triple complex with charge transfer $\mathrm{HEMA} / \mathrm{Ni}^{2+} / \mathrm{PVP}$

At the same time, the formation of a complex with a charge transfer, which is accompanied by the formation of intermolecular contacts between the monomer, metal ion and carbamate groups of the PVP chain [7,8], contributes to a uniform distribution of the formed metallic particles in the polymer matrix volume, even at the stage of mixing the initial composition components. Such interaction resulted in the coordination of $\mathrm{Ni}^{2+}$ ions (Fig. 2) followed by the stabilization of the formed $\mathrm{Ni}(0)$ particles.

Considering the self-heating of the PMC during polymerization, the kinetics of the reaction was investigated by a thermometric method. The characteristic kinetic parameters of the exothermic process, $\tau_{\text {s.f. }}, \tau_{\text {d.e. }}$ and $\mathrm{T}_{\max }$, are highlighted in the received thermometric curves (Fig. 3,a). Depending on the type of initiatial system, the process is performed at an appropriate initial polymerization temperature $\left(\mathrm{T}_{0}\right)[7,8]$. An increase in the polymerization temperature evidently contributes to increasing the rate of polymerization processes, the maximum exothermic temperature, and therefore the rate of $\mathrm{Ni}(0)$ deposition (Fig. 3,a). In the case of PVP/HEMA, polymerization occurs at a high rate in the presence of BP already at a temperature of $50^{\circ} \mathrm{C}$ (the value $\mathrm{T}_{\max }=97^{\circ} \mathrm{C}$ is reached after $34 \mathrm{~min}$ with $\tau_{\text {d.e. }}=27 \mathrm{~min}$ ) (Fig. 3,a). Therefore, we accept the initial temperature of polymerization $\mathrm{T}_{0}=50^{\circ} \mathrm{C}$. At higher initial temperatures, $T_{\max }$ increases to 110 $130^{\circ} \mathrm{C}$.

The concentration of $\mathrm{BP}$ was changed in the range of 0.1 to $0.5 \mathrm{wt} . \%$. At $\mathrm{T}_{0}=50^{\circ} \mathrm{C}$ and the initiator content of $0.1 \mathrm{wt} . \%$, the process was characterized by a long induction period with a followed gel-effect that appeared after $67 \mathrm{~min}$. In this case, the maximum exothermic temperature $\left(116.8^{\circ} \mathrm{C}\right)$ was reached after 86 min (Fig. 3,b). With an increase in the initiator concentration, $\mathrm{T}_{\max }$ increased. Besides, the start time of the gel-effect was significantly reduced. With an increase in the BP content up to $0.3 \mathrm{wt} \%$, a minimum time $\tau_{\text {s.g. }}$ was reached (it changed slightly with subsequent growth of $[\mathrm{BP}])$. Therefore, we further used the concentration $[\mathrm{BP}]=0.3 \mathrm{wt} . \%$.

At the same time, it was determined that the contents of solvent, HEMA and PVP in the initial composition have a versatile effect on the parameters of the exothermic process. With an increase in the PVP content in the composition, its polymerization ability increases too and the start time of gel formation decreases accordingly (Fig. 4,a). An increase in the PVP content in the PMC accelerates the onset of exothermicity, however, leads to a decrease in the value of $\mathrm{T}_{\max }$. In this case, the $\mathrm{T}_{\max }$ decrease can be explained by a decrease in the monomer content in PMC, which causes an intense heat release.

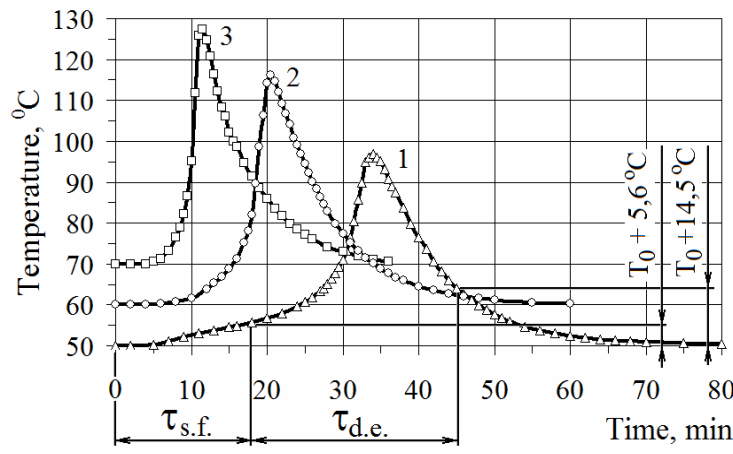

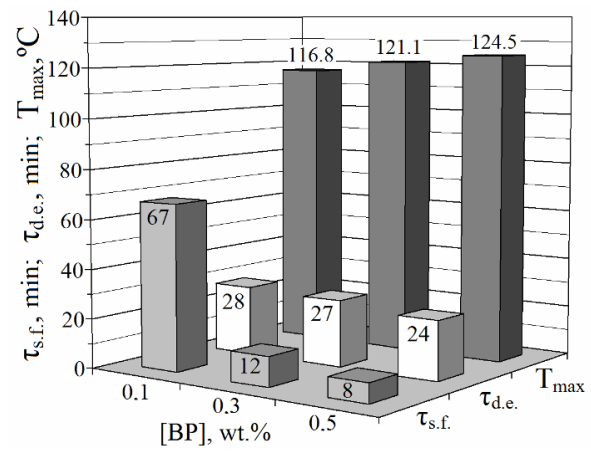

b

Fig. 3. (a) - Thermometric curves of polymerization recorded at different initial temperatures $\left(\mathrm{T}_{0},{ }^{\circ} \mathrm{C}\right): 1-50 ; 2-60$; $3-70$ (HEMA:PVP: $\mathrm{H}_{2} \mathrm{O}=80: 20: 25$ m.p.); (b) - the effect of on the polymerization parameters at different BP content (HEMA:PVP: $\mathrm{H}_{2} \mathrm{O}=80: 20: 10$ m.p.) 

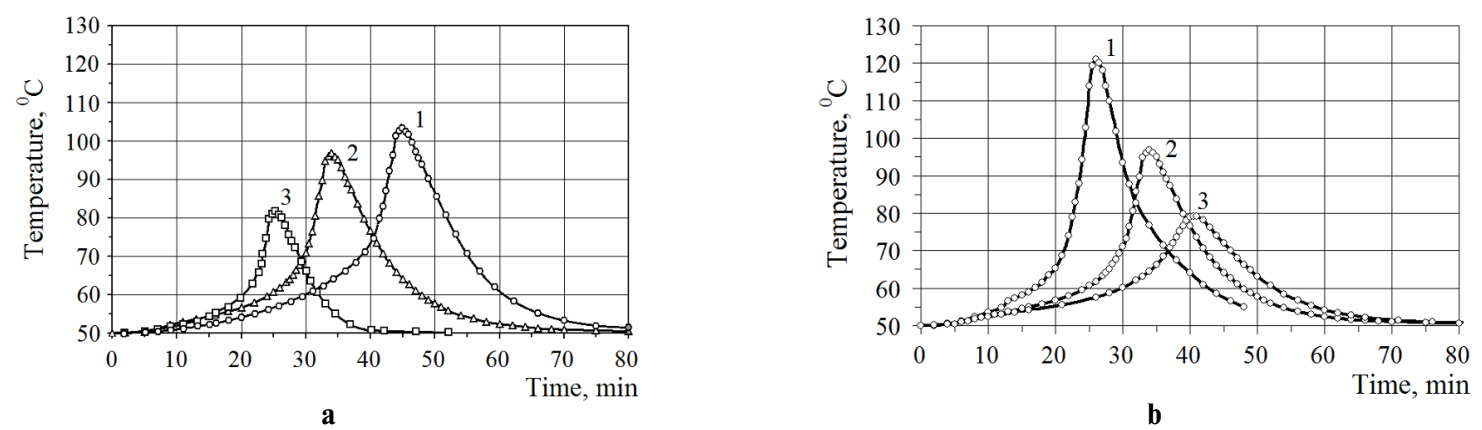

Fig. 4. Thermometric curves of polymerization recorded (a) at different compositions HEMA:PVP: $\mathrm{H}_{2} \mathrm{O}$ (m.p.): 1 - 90:10:25; $2-80: 20: 25 ; 3-70: 30: 25$; and (b) at different content of the solvent (m.p.): $1-10 ; 2-25 ; 3-50$ (HEMA:PVP=80:20 m.p.,

$[\mathrm{BP}]=0.3 \mathrm{wt} . \%)$

Reduction of the monomer concentration, resulted from the dilution of the composition by a solvent, naturally causes a decrease in the initial polymerization rate. This indicates increasing the start time of gel-effect and reaching the maximum exothermic temperature (Fig. 4,b). An increase in the water content from 10 m.p. up to 50 m.p. causes a decrease in the $\mathrm{T}_{\max }$ value from $121^{\circ} \mathrm{C}$ to $79^{\circ} \mathrm{C}$ and an increase in $\tau_{\text {s.g. }}$. At the same time, it should be noted that the gel-effect area changes only slightly.

As can be seen, the content of solvent, HEMA and PVP has a diverse influence on the parameters of the exothermic process. The optimal content of the initial components, at which the required parameters of the exothermic process are achieved, cannot be found experimentally. Therefore, to investigate the simultaneous influence of initial composition on the exothermic process parameters, we used the optimization of the experiment by means of simplex-lattice planning Scheffe that allows reducing the experimental expenses [15]. The result of this research will be a multifactor mathematical model in the form of a polynomial of a given degree.

The simplex method requires the fulfillment of the following condition for each experimental point:

$$
\Sigma \mathrm{X}_{\mathrm{i}}=1
$$

where $X_{i} \geq 0$ is the concentration of the $\mathrm{i}$-th component in the composition.

The mixtures properties depend only on three factors and the factor space is an equilateral triangle. Then, the following equation should be valid for the system under consideration [15]:

$$
\mathrm{X}_{1}+\mathrm{X}_{2}+\mathrm{X}_{3}=1 \text {. }
$$

The vertices of the triangle correspond to the pure substances, and the sides are related to the double systems. In our case, we did not investigate the whole concentration triangle, however, only its local part was examined, which was a simplex with vertices $\mathrm{A}_{1}\left(72 \%\right.$ HEMA, 8\% PVP and $20 \% \mathrm{H}_{2} \mathrm{O}$ ); $\mathrm{A}_{2}$ (56\% HEMA, 24\% PVP and 20\% $\mathrm{H}_{2} \mathrm{O}$ ); and $\mathrm{A}_{3}$ (56\% HEMA, 8\% PVP and $36 \% \mathrm{H}_{2} \mathrm{O}$ ) (Fig. 5).

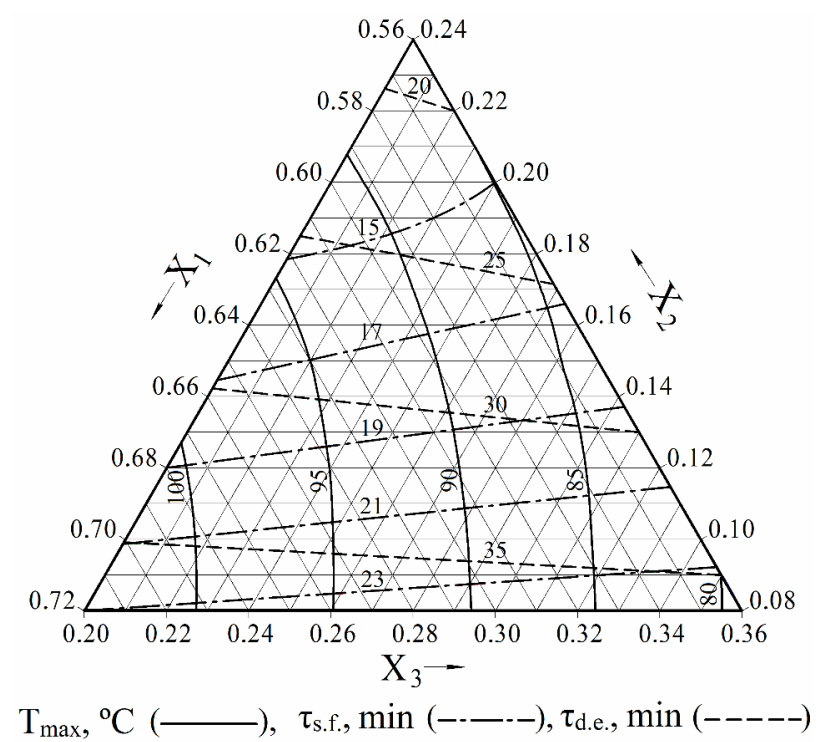

Fig. 5. Equal values lines of parameters of the exothermic process

It should be noted that $\mathrm{X}_{1}, \mathrm{X}_{2}$ and $\mathrm{X}_{3}$ denote HEMA (wt.\%), PVP (wt.\%) and $\mathrm{H}_{2} \mathrm{O}$ (wt.\%), respectively. The lower limit of the PVP content is because the duration of the induction period significantly increases with its lower content. The upper limit is caused by the technological complications. This means that an increase in the content of PVP results in increasing both the duration of its dissolution in acrylates and the viscosity of the composition; however, $\tau_{\text {d.e. }}$ and $\mathrm{T}_{\max }$ values significantly decrease. The necessity of $\mathrm{H}_{2} \mathrm{O}$ presence in the original composition is caused by the dissolution of the oxidizer and reducing agent, that 
explains the minimum solvent content $(20 \%)$. In addition, with a lower content of $\mathrm{H}_{2} \mathrm{O}, \tau_{\text {d.e }}$ sharply decreases and $\mathrm{T}_{\max }$ exceeds $110^{\circ} \mathrm{C}$. The dilution of the composition by the solvent in amount above $36 \%$ causes an increase of the induction period and a decrease of $T_{\max }$ value.

The optimization was carried out for the following exothermic parameters: the start time of the gel formation $\left(\tau_{\text {s.f. }}, \min \right)$, gel-effect area $\left(\tau_{\text {d.e. }}\right.$, min) and the maximum exothermic temperature $\left(\mathrm{T}_{\max },{ }^{\circ} \mathrm{C}\right)$. Table shows the conditions and the results of experiments in the form of pseudo-components and in a natural scale. The average results, $y_{1 e}\left(T_{\max }\right.$, $\left.{ }^{0} \mathrm{C}\right), \mathrm{y}_{2 \mathrm{e}}\left(\tau_{\text {s.f. }}, \mathrm{min}\right)$ and $\mathrm{y}_{3 \mathrm{e}}\left(\tau_{\text {d.e. }}, \mathrm{min}\right)$, were obtained in two parallel experiments.

\section{Conditions and results of experiments}

\begin{tabular}{c|c|c|c|c|c|c}
\hline \multirow{2}{*}{ No. } & \multicolumn{3}{|c|}{ Natural variables } & \multirow{2}{*}{$\mathrm{y}_{1 \mathrm{e}}$} & \multirow{2}{*}{$\mathrm{y}_{2 \mathrm{e}}$} & \multirow{2}{*}{$\mathrm{y}_{3 \mathrm{e}}$} \\
\cline { 2 - 4 } & $\mathrm{X}_{1}$ & $\mathrm{X}_{2}$ & $\mathrm{X}_{3}$ & & \\
\hline 1 & 0.72 & 0.08 & 0.20 & 103.5 & 23.00 & 37.00 \\
\hline 2 & 0.56 & 0.24 & 0.20 & 84.40 & 13.00 & 18.20 \\
\hline 3 & 0.56 & 0.08 & 0.36 & 79.00 & 24.20 & 36.50 \\
\hline 4 & 0.64 & 0.16 & 0.20 & 96.80 & 16.00 & 28.00 \\
\hline 5 & 0.64 & 0.08 & 0.28 & 92.00 & 23.70 & 36.90 \\
\hline 6 & 0.56 & 0.16 & 0.28 & 84.00 & 17.40 & 26.40 \\
\hline
\end{tabular}

Using the matrix of planning, adopted conditions and the results of the experiment (Table), the coefficients of the polynomial were calculated and the following regression equations were derived:

$$
\begin{aligned}
& \mathrm{y}_{1}=123.44+63.75 \mathrm{X}_{2}-71.25 \mathrm{X}_{3}- \\
& -203.13 \mathrm{X}_{2} \mathrm{X}_{3}-445.31 \mathrm{X}_{2}^{2}-117.19 \mathrm{X}_{3}^{2} \\
& \mathrm{y}_{2}=33.13-184.38 \mathrm{X}_{2}+7.5 \mathrm{X}_{3}+ \\
& +109.38 \mathrm{X}_{2} \mathrm{X}_{3}+312.5 \mathrm{X}_{2}^{2}-15.63 \mathrm{X}_{3}^{2} \\
& \mathrm{y}_{3}=40.39-50.63 \mathrm{X}_{2}+28.75 \mathrm{X}_{3}- \\
& -234.38 \mathrm{X}_{2} \mathrm{X}_{3}-62.5 \mathrm{X}_{2}^{2}-23.44 \mathrm{X}_{3}^{2} .
\end{aligned}
$$

The obtained equations allow predicting the change of the parameters for the exothermic copolymerization of HEMA with PVP: the start time of gel formation $\left(\mathrm{y}_{1}\right)$, the gel-effect area $\left(\mathrm{y}_{2}\right)$ and the maximum exothermic temperature $\left(\mathrm{y}_{3}\right)$ for any composition of the initial composition.

According to the obtained regression equations, the isolines of the exothermic parameters change were plotted as functions of the content of each component in the original composition (Fig. 5). The obtained lines of equal values of parameters significantly simplify the experimental search for the contents of the components concentrations in the reaction composition in order to obtain optimal technological conditions for the nickel deposition during the polymerization.

The established parameters of time and temperature in the processes of $\mathrm{Ni}^{2+}$ reduction and polymerization of PVP/HEMA compositions and the main factors that affect these parameters will provide the opportunity to substantiate the technological conditions for the preparation of the metal-filled copolymers Ni/pHEMA-gr-PVP.

\section{Conclusions}

The kinetic characteristics of the nickel reduction reaction by hypophosphite were studied by means of volumetric method. It was established that the chemical precipitation of a metal in a weakly alkaline medium was characterized by a high rate and a low induction period already at the temperature of $60-70^{\circ} \mathrm{C}$. It was determined that the presence of PVP reduced both the duration of the induction period and the reaction rate.

The kinetics of heat release during polymerization of HEMA/PVP compositions, initiated by benzoyl peroxide, was investigated by a thermometric method. The onset time of the gel effect and the maximum exothermic temperature mainly depend on the composition of the initial mixture, solvent content and initial temperature of polymerization.

Using the Scheffe's simplex-lattice planning method, the parameters of the polymerization of HEMA/PVP compositions were determined. The plotted lines of equal values of parameters will significantly simplify the experimental search for the composite formula with given parameters of the exothermicity of the polymerization process, depending on the nature of a co-deposited metal.

\section{Acknowledgments}

The publication reports the results of the studies conducted under the grant of President of Ukraine (projects $\Phi 84 / 56870$ ) and within the framework of the National Scholarship Program of the Slovak Republic (SAIA).

\section{REFERENCES}

1. Nicolais L., Carotenuto G. Metal-polymer nanocomposites. - New Jersey: John Wiley \& Sons, 2004. - 320 p.

2. Features of the production of metal-filled composites by metallization of polymeric raw materials / Moravskyi V., Dziaman I., Suberliak S., et al. // Proceedings of the 7th International 
Conference on Nanomaterials: Applications and Properties. Zatoka. - 2017. - P.1-4.

3. Electrical elements of the optical systems based on hydrogel-electrochromic polymer composites / Bashtyk Yu., Fechan A., Grytsenko O., et al. // Mol. Cryst. Liq. Cryst. 2018. - Vol.672. - No. 1. - P.150-158.

4. Review on polymer, hydrogel and microgel metal nanocomposites: a facile nanotechnological approach / Thomas V., Namdeo M., Murali Mohan Y., et al. // J. Macromol. Sci. 2007. - Vol.45. - No. 1. - P.107-119.

5. Pal K., Banthia A.K., Majumdar D.K. Polymeric hydrogels: characterization and biomedical applications // Des. Monomers Polym. - 2009. - Vol.12. - No. 3. - P.197-220.

6. Serrano-Aroca A. Enhancement of hydrogels' properties for biomedical applications: latest achievements // Hydrogels. London: IntechOpen, 2018. - P.91-120.

7. Technological features in obtaining highly effective hydrogel dressings for medical purposes / Grytsenko O., Pokhmurska A., Suberliak S., et al. // Eastern-Eur. J. Enterprise Technol. - 2018. - Vol.6. - No. 6/96. - P.6-13.

8. Novel Ni/pHEMA-gr-PVP composites obtained by polymerization with simultaneous metal deposition: structure and properties / Grytsenko O., Gajdos I., Spisak E., Krasinskyi V., Suberlyak O. // Materials. - 2019. - Vol.12. - Article No. 1956.

9. Suberlyak O.V., Hrytsenko O.M., Hischak Kh.Ya. Influence of the metal surface of powder filler on the structure and properties of composite materials based on the copolymers of methacrylates with polyvinylpyrrolidone // Mater. Sci. - 2016. - Vol. 52. - P.155-164.

10. Skorokhoda $V$. Matrix polymerization of 2-hydroxyethylmethacrylate in the presence of polyvinylpyrrolidone in permanent magnetic field // Chem. Chem. Technol. - 2010. Vol.4. - P. 191-196.

11. Dzyaz'ko Y.S., Rozhdestvenskaya L.M., Pal'chik A.V. Recovery of nickel ions from dilute solutions by electrodialysis combined with ion exchange // Russ. J. Appl. Chem. - 2005. Vol.78. - P. 414-421.

12. Chemical precipitation of metals from water solutions / Sviridov V.V., Vorobyova T.N., Gayevskaya T.V., Stepanova L.I. - Minsk: Universitetskoe, 1987. - 267 p.

13. Research into kinetic patterns of chemical metallization of powder-like polyvinylchloride / Moravskyi V., Dziaman I., Suberliak S., et al. // Eastern-Eur. J. Enterprise Technol. - 2017. - Vol.4. - No. 12(88). - P.50-57.

14. Bekturov E.A., Iskakov R.M., Shmakov C.Y. Investigation of copper, cobalt and nickel nanoparticles by electron transmission spectroscopy // Sci. Cent. Asia. - 2010. - No. 2-3. - P.34-37.

15. Akhnazarova S.L., Kafarov V.V. Metody optimizatsii eksperimenta v khimicheskoi tekhnologii. - M.: Vysshaya shkola, 1985. $-319 \mathrm{p}$.

\section{ОПТИМІЗАЦІЯ ТЕХНОЛОГІЧНИХ ПАРАМЕТРІВ ПРОЩЕСУ ПРИЩЕПЛЕНОЇ КОПОЛІМЕРИЗАЩІЇ 2- ГІДРОКСІЕТИЛМЕТАКРИЛАТУ 3 ПОЛІВІНІЛПІРОЛІДОНОМ ДЛЯ ОСАДЖЕННЯ НІКЕЛЮ 3 СОЛЕЙ}

О.М. Гриценко, О.П. Науменко, О.В. Суберляк, Л. Дулебова, Б.В. Бережний

Досліджено основні технологічні параметри процесу одержання нікельнаповнених гідрогельних матеріалів на основі кополімерів полівінілпіролідону з 2-гідроксіетилметакрилатом методом полімеризації з одночасним відновленням іонів металу. За допомогою волюмометричного методу встановлено, що за pH 7,5-8,0 процес хімічного відновлення іонів нікелю характеризується високою швидкістю та малим індукційним періодом вже за температури $60-70^{\circ}$ C. Виявлено, що присутність полівінілпіролідону зменшуе тривалість індукційного періоду та підвишує швидкість реакції відновлення. Термометричним методом досліджено кінетику виділення тепла під час кополімеризації 2-гідроксіетилметакрилату з полівінілпіролідоном, ініційованої пероксидом бензоїлу. Встановлено, що екзотермічний ефект полімеризації можнн використати для створення необхідних температурних умов для відновлення $\mathrm{Ni}^{2+}$. Експериментально доведено різносторонній вплив складу вихідної полімер-мономерної композиції на основні параметри процесу екзотермії кополімеризації. Залежно від вмісту полівінілпіролідону, ініціатора, розчинника та початкової температури полімеризації максимальна температура екзотермії змінюється від 80 до $130^{\circ} \mathrm{C}$, а час ї̈ настання - від 11 до 86 хв. 3 метою зменшення частки експериментальних затрат, доведена можливість використання методу симплекс-градкового планування для оптимізації складу полімер-мономерної композиції. Одержані рівняння регресії дозволяють аналітично встановити взаємозв'язок параметрів екзотермічних процесів з технологічними умовами відновлення іонів $\mathrm{Ni}^{2+}$, а також зі складом полімер-мономерної композицї.

Ключові слова: полівінілпіролідон, 2-гідроксіетилметакрилат, металонаповнені гідрогелі, екзотермічна полімеризація, хімічне відновлення, оптимізація, симплексградкове планування.

Received 30.09.2019

Optimization of the technological parameters of the graft copolymerization of 2-hydroxyethyl methacrylate with polyvinylpyrrolidone for nickel deposition from salts 


\section{OPTIMIZATION OF THE TECHNOLOGICAL PARAMETERS OF THE GRAFT COPOLYMERIZATION OF 2-HYDROXYETHYL METHACRYLATE WITH POLYVINYLPYRROLIDONE FOR NICKEL DEPOSITION FROM SALTS \\ O.M. Grytsenko ${ }^{a,}$, , O.P. Naumenko ${ }^{b}$, O.V. Suberlyak ${ }^{a}$, \\ L. Dulebova ${ }^{c}$, B.V. Berezhnyy ${ }^{a}$ \\ a Lviv Polytechnic National University, Lviv, Ukraine \\ b Ukrainian State University of Chemical Technology, Dnipro, Ukraine \\ c Technical University of Košice, Košice, Slovakia \\ * e-mail: ogryts@gmail.com}

The basic technological parameters of the preparation of nickel-filled hydrogel materials based on copolymers of polyvinylpyrrolidone with 2-hydroxyethyl methacrylate by the method of polymerization with simultaneous recovery of metal ions were considered. It was established by volumetric method that the process of chemical reduction of nickel ions at $p H 7.5-8$ is characterized by a high rate and a small induction period at a temperature of $60-$ $70^{\circ} \mathrm{C}$. The presence of polyvinylpyrrolidone was found to reduce the duration of the induction period and increase the rate of the reduction reaction. The duration of the induction period is 14 minutes when the content of polyvinylpyrrolidone in solution is $200 \mathrm{~g} / \mathrm{L}$. The kinetics of heat release during copolymerization of 2-hydroxyethyl methacrylate with polyvinylpyrrolidone initiated by benzoyl peroxide was investigated by a thermometric method. It was established that the exothermic effect of the polymerization can be used to ensure the required temperature conditions for $\mathrm{Ni}^{2+}$ reduction. The versatile effect of the composition of the original polymer-monomer composition on the basic parameters of the exotherm process of copolymerization has been experimentally shown. The diversified effect of the composition of the initial polymer-monomer composition on the parameters of the exothermicity of the copolymerization was experimentally determined. The simplex-lattice planning method was used to optimize the formula of polymer-monomer composition. The obtained regression equations allow establishing analytical dependences of the parameters of exothermic processes on the technological conditions of the reduction of $\mathrm{Ni}^{2+}$ ions and the formula of the polymer-monomer composition.

Keywords: polyvinylpyrrolidone; 2-hydroxyethylmethacrylate; metal-filled hydrogels; exothermic polymerization; chemical reduction; optimization; simplex-lattice planning.

\section{REFERENCES}

1. Nicolais L., Carotenuto G., Metal-polymer nanocomposites. John Wiley \& Sons, New Jersey, 2005. 304 p.

2. Moravskyi V., Dziaman I., Suberliak S., Grytsenko O., Kuznetsova M., Features of the production of metal-filled composites by metallization of polymeric raw materials. Proceedings of the 7th International Conference on Nanomaterials: Applications and Properties. Ukraine, Zatoka, 2017, pp. 1-4.

3. Bashtyk Yu., Fechan A., Grytsenko O., Hotra Z., Kremer I., Suberlyak O., Aksimentyeva O., Horbenko Yu., Kotsarenko M. Electrical elements of the optical systems based on hydrogelelectrochromic polymer composites. Molecular Crystals and Liquid Crystals, 2018, vol. 672, pp. 150-158.

4. Thomas V., Namdeo M., Murali Mohan Y., Bajpai S.K., Bajpai M. Review on polymer, hydrogel and microgel metal nanocomposites: a facile nanotechnological approach. Journal of Macromolecular Science, Part A: Pure and Applied Chemistry, 2007, vol. 45, pp. 107-119.
5. Pal K., Banthia A.K., Majumdar D.K. Polymeric hydrogels: characterization and biomedical applications. Designed Monomers and Polymers, 2009, vol. 12, pp. 197-220.

6. Serrano-Aroca A., Enhancement of hydrogels' properties for biomedical applications: latest achievements. In: Haider S., Haider A. (eds.) Hydrogels. IntechOpen: London, 2018, pp. 91120. Available from: http://dx.doi.org/10.5772/intechopen.71671.

7. Grytsenko O., Pokhmurska A., Suberliak S., Kushnirchuk M., Panas M., Moravskyi V., Kovalchuk R. Technological features in obtaining highly effective hydrogel dressings for medical purposes. Eastern-European Journal of Enterprise Technologies, 2018, vol. 6, no. 6/96, pp. 6-13.

8. Grytsenko O., Gajdos I., Spisak E., Krasinskyi V., Suberlyak O. Novel Ni/pHEMA-gr-PVP composites obtained by polymerization with simultaneous metal deposition: structure and properties. Materials, 2019, vol. 12, article no. 1956.

9. Suberlyak O.V., Hrytsenko O.M., Hischak Kh.Ya. Influence of the metal surface of powder filler on the structure and properties of composite materials based on the copolymers of methacrylates with polyvinylpyrrolidone. Materials Science, 2016, vol. 52, pp. 155-164.

10. Skorokhoda V. Matrix polymerization of 2-hydroxyethylmethacrylate in the presence of polyvinylpyrrolidone in permanent magnetic field. Chemistry \& Chemical Technology, 2010, vol. 4, pp. 191-196.

11. Dzyaz'ko Yu.S., Rozhdestvenskaya L.M., Pal'chik A.V. Recovery of nickel ions from dilute solutions by electrodialysis combined with ion exchange. Russian Journal of Applied Chemistry, 2005, vol. 78, pp. 414-421.

12. Sviridov V.V., Vorobyova T.N., Gayevskaya T.V., Stepanova L.I. Khimicheskoe osazhdenie metallov iz vodnykh rastvorov [Chemical precipitation of metals from aqueous solutions]. Universitetskoe Publishers, Minsk, 1987. 267 p. (in Russian).

13. Moravskyi V., Dziaman I., Suberliak S., Kuznetsova M., Tsimbalista T., Dulebova L. Research into kinetic patterns of chemical metallization of powder-like polyvinylchloride. EasternEuropean Journal of Enterprise Technologies, 2017, no. 4(12), pp. 50-57.

14. Bekturov E.A., Iskakov R.M., Shmakov C.Y. Investigation of copper, cobalt and nickel nanoparticles by electron transmission spectroscopy. Science of Central Asia, 2010, no. 2-3, pp. 34-37.

15. Akhnazarova S.L., Kafarov V.V., Metody optimizatsii eksperimenta $v$ khimicheskoi tekhnologii [Methods of experiment optimization in chemical technology]. Vysshaya Shkola Publishers, Moscow, 1985. 319 p. (in Russian). 